University of Nebraska - Lincoln

DigitalCommons@University of Nebraska - Lincoln

Publications from USDA-ARS / UNL Faculty

U.S. Department of Agriculture: Agricultural

Research Service, Lincoln, Nebraska

$9-21-2001$

\title{
Thermoregulatory profile of a newer genetic line of pigs
}

T. M. Brown-Brandl

USDA-ARS US Meat Animal Research Center, Tami.BrownBrandl@ARS.USDA.GOV

R. A. Eigenberg

USDA-ARS US Meat Animal Research Center, reigenberg2@unl.edu

John A. Nienaber

University of Nebraska-Lincoln, jnienaber2@unl.edu

Stephen D. Kachman

University of Nebraska-Lincoln, steve.kachman@unl.edu

Follow this and additional works at: https://digitalcommons.unl.edu/usdaarsfacpub

Part of the Agricultural Science Commons

Brown-Brandl, T. M.; Eigenberg, R. A.; Nienaber, John A.; and Kachman, Stephen D., "Thermoregulatory profile of a newer genetic line of pigs" (2001). Publications from USDA-ARS / UNL Faculty. 178. https://digitalcommons.unl.edu/usdaarsfacpub/178

This Article is brought to you for free and open access by the U.S. Department of Agriculture: Agricultural Research Service, Lincoln, Nebraska at DigitalCommons@University of Nebraska - Lincoln. It has been accepted for inclusion in Publications from USDA-ARS / UNL Faculty by an authorized administrator of DigitalCommons@University of Nebraska - Lincoln. 


\title{
Thermoregulatory profile of a newer genetic line of pigs
}

\author{
T.M. Brown-Brandl ${ }^{\text {a } *}$, R.A. Eigenberg ${ }^{\text {a }}$, J.A. Nienaber ${ }^{\text {a }}$, S.D. Kachman ${ }^{\text {b }}$ \\ ${ }^{a}$ USDA-ARS US Meat Animal Research Center, P.O. Box 166, Clay Center, NE 68933, USA \\ ${ }^{\mathrm{b}}$ University of Nebraska, 103 Miller Hall, Lincoln, NE 68583, USA
}

Received 28 August 2000; received in revised form 29 January 2001; accepted 12 February 2001

\begin{abstract}
Researchers and producers alike have noted the increased susceptibility to heat stress exhibited by the newer genetic lines of pigs. A study was conducted to gather baseline information on the effects of acute heat stress on total heat production (THP), respiratory quotient $(\mathrm{RQ})$, respiration rate $(\mathrm{RR})$, and rectal temperature $\left(T_{\text {rectal }}\right)$ and to investigate the dynamic interaction of these parameters in growing-finishing barrows. Sixteen moderate-lean growth barrows were randomly assigned to a set of treatments as dictated by a repeated $4 \times 4$ Latin square crossover design. Pigs were moved from an individual pen to an indirect calorimeter where one of four environmental treatments $\left(18,24,28,32^{\circ} \mathrm{C}\right)$ were applied for 20 h. During the treatment exposure RR, THP, RQ and $T_{\text {rectal }}$ were measured. For the 2-week period between treatments, pigs were housed at thermoneutral $\left(22^{\circ} \mathrm{C}\right)$. THP was found to be $17-20 \%$ higher than the published standards but comparable with other contemporary studies. Respiration rate was found to be a leading indicator of stress. Published by Elsevier Science B.V.
\end{abstract}

Keywords: Pig; Thermoregulation; Temperature; Respiratory quotient; Calorimetry

\section{Introduction}

It has been suggested that the swine housing standards need to be updated (Brown-Brandl et al., 1998; Harmon et al., 1997), since many of the current standards are based on data from Bond et al. (1959). Brown-Brandl et al. (1998) reported total heat production (THP) in finishing swine $26 \%$ higher under thermal neutral conditions than the current

\footnotetext{
*Corresponding author. Tel.: +1-402-762-4279; fax: +1-402762-4273.

E-mail address: brandl@email.marc.usda.gov (T.M. BrownBrandl).
}

standards. Harmon et al. (1997) reported THP in early weaned pigs $33 \%$ higher and moisture production $70-135 \%$ higher than the current standards (ASAE, 1999).

It has been suggested that these increases in THP are associated with increases in lean tissue deposition. An equation was developed by van Milgen et al. (1998) for fasting heat production (FHP) for different genotypes of pigs expressed as a function of muscle, fat, and viscera showing that FHP linearly increases with percent muscle. The added heat production of the higher-lean growth swine put increased pressures on the animals to maintain homeothermy under warm or hot environments. Threshold temperatures calculated by Nienaber et al. 
(1997) were approximately $4^{\circ} \mathrm{C}$ lower for the newer genetics than the moderate-growth genetics.

Respiration rate (RR) and rectal temperature $\left(T_{\text {rectal }}\right)$ are two good indicators of thermal stress. As temperatures increase sensible heat losses decrease; the animal must rely more on latent heat losses to dissipate heat produced. Since swine increase latent losses by panting, RR increases as temperature increases in order to maintain homeothermy. BrownBrandl et al. (1998) used an exponential function to describe this relationship. Although $T_{\text {rectal }}$ is dynamic by nature and has an intrinsic diurnal pattern, it is a good indication of level of stress. The current $T_{\text {rectal }}$, mean $T_{\text {rectal }}$ over the course of the day, and a fractal dimension (a measure of the "roughness" of the curve) calculated from $T_{\text {rectal }}$ have all been used to determine level of stress (Hahn et al., 1993).

With the increase in lean-tissue accretion and the subsequent increase in THP, the high-lean growth swine have become increasingly susceptible to thermal stress. An understanding of interactions of the thermoregulatory parameters would aid in the development of management tools.

The objectives of this study were to investigate the effects of acute heat stress on growing and finishing swine, and the interactions of thermoregulatory variables under various thermal conditions.

\section{Materials and methods}

Sixteen Yorkshire $\times$ Landrace barrows, eight pairs of littermates, selected on the basis of weight, were assigned to individual pens in one of three rooms for a 2-week acclimation period.

Ambient conditions in the rooms remained at thermoneutral $\left(<22^{\circ} \mathrm{C}\right)$. Pigs were allowed adlibitum access to feed (corn-soy diet; ME: $15 \mathrm{MJ} / \mathrm{kg}$, $13.6 \%$ crude protein) and water throughout the experiment. Pigs were subjected to a $12 \mathrm{~L}: 12 \mathrm{D}$ lighting regime with lights on at 06:00 h.

Pigs were assigned to one of two groups on the basis of litter where no littermates were assigned to the same group. Each day three animals were individually moved to one of three calorimeters (1 animal/calorimeter/day) for a 20-h acute exposure to one of four temperatures $\left(18,24,28,32^{\circ} \mathrm{C}\right)$, where over the course of the experiment every animal was exposed to every temperature and had at least one exposure in each calorimeter. There were four periods during the experiment; animals in group 1 were exposed to temperature treatments during the first week of every period and animals in group 2 were exposed to temperature treatments during the second week of every period (Table 1). Treatments were imposed according to a repeated Latin square statistical design balanced for crossover effects (Kuehl, 1994). The relative humidity was approximately $40 \%$ and the air movement over the animals was minimal $(<0.15 \mathrm{~m} / \mathrm{s})$ for all temperature treatments. Ambient temperature was measured using a linear temperature sensor (National Semiconductor Part No. LM35CAZ-ND, Crawfordsville, IN, USA). Moisture in the air was recorded by an absolute humidity sensor (ABS-300, Ohmic Instruments, Easton, MD, USA). Each calorimeter measurement began between 11:30 and 13:00 $\mathrm{h}$ and ended the following morning between 07:30 and 09:00 h.

During the dark period low wattage red bulbs were used above each calorimeter to provide adequate lighting for the video cameras. While in the

Table 1

Experimental design for period $\mathrm{I}^{\mathrm{a}}$

\begin{tabular}{lllll}
\hline & Day & Animal & Treatment & Calorimeter \\
\hline Group I - week 1 & 1 & 1 & 18 & 1 \\
& 1 & 2 & 28 & 2 \\
& 2 & 4 & 32 & 1 \\
& 1 & 3 & 24 & 3 \\
& 2 & 5 & 18 & 2 \\
& 2 & 6 & 24 & 3 \\
& 3 & 7 & 28 & 1 \\
& 3 & 8 & 32 & 2 \\
Group II - week 2 & 1 & 9 & 18 & 1 \\
& 1 & 10 & 32 & 2 \\
& 1 & 11 & 28 & 3 \\
& 2 & 12 & 24 & 2 \\
& 2 & 13 & 32 & 3 \\
2 & 14 & 24 & 1 \\
& 3 & 15 & 18 & 3 \\
& 3 & 16 & 28 & 2 \\
\hline
\end{tabular}

\footnotetext{
${ }^{a}$ Other periods (II, III, IV) were similar but different treatments assigned to the animals such that all animals were exposed to all treatments and all calorimeters. Also, all treatments were in each of the three calorimeters an equal number of times.
} 
calorimeter, $\mathrm{RR}, T_{\text {rectal }}, \mathrm{CO}_{2}$ and $\mathrm{CH}_{4}$ production, $\mathrm{O}_{2}$ consumption, and feed intake were measured and activity was videotaped. Pigs were weighed before and after each calorimeter measurement. Respiration rate was measured with an acoustic respiration sensor (Eigenberg et al., 2000). The respiration signal was recorded on a Tattletale TFX-11 (Onset Computer Corporation, Bourne, MA, USA) at $10 \mathrm{~Hz}$ for $1 \mathrm{~min}$ every $10 \mathrm{~min}$. Rectal thermistor probes and Pace pocket loggers (Pace Scientific, Charlotte, NC, USA) were used to record $T_{\text {rectal }}$ every $1 \mathrm{~min}$. Pigs were fitted with a nylon mesh vest and a pouch to hold the data loggers at least $24 \mathrm{~h}$ prior to the treatment, allowing the pigs to acclimate to the vest. After the $20 \mathrm{~h}$ exposure the animals were returned to their pen, where they were housed at thermoneutral conditions $\left(<22^{\circ} \mathrm{C}\right)$ for the 2 -week period between exposures.

Total heat production was calculated using indirect calorimetry methods (Nienaber and Maddy, 1985). A calorimeter gas sample was collected in a myler bag over a 20-h period and analyzed after the run for $\mathrm{O}_{2}$, $\mathrm{CO}_{2}$ and $\mathrm{CH}_{4}$. This served as the basis for calculating the batch THP measurements. The dynamic THP was calculated from gas samples analyzed every 10 min during the run. Oxygen and $\mathrm{CO}_{2}$ were measured within $100 \mathrm{ppm}$, while methane concentrations were measured within $10 \mathrm{ppm}$. Respiration quotient (RQ) was calculated by dividing total liters of $\mathrm{CO}_{2}$ produced by total liters of $\mathrm{O}_{2}$ consumed, based on the batch measurements.

Activity was videotaped during each calorimetry run with cameras located outside of each calorimeter. After pigs were placed in the calorimeter, a curtain was drawn and maintenance activity in the room was kept to a minimum to reduce disruptions of the animals. The videotapes were viewed in their entirety by one of four people (two tapes, blocked on group, were randomly assigned to each person) and activity was classified as standing, lying, or eating. Total time spent at each activity was then summed and divided by the total run time. The cost of activity was reported as $418.8 \mathrm{~kJ} /$ day $\mathrm{kg}^{0.75}$ by McDonald et al. (1988), $417.6 \mathrm{~kJ} /$ day $\mathrm{kg}^{0.75}$ by Noblet et al. (1993) and 400.8 by van Milgen et al. (1998). The cost of activity was estimated to be $412.2 \mathrm{~kJ} /$ day $\mathrm{kg}^{0.75}$, the average of the three values. To quantify the effect of activity on THP, the following equation was developed to calculate a resting heat production value which removes the effects of activity on THP

$\mathrm{RHP}=\mathrm{THP}-C \cdot A / T$

where $\mathrm{RHP}=$ resting heat production $\left(\mathrm{kJ} / \mathrm{day} \mathrm{kg}^{0.75}\right)$, $\mathrm{THP}=$ total heat production $\left(\mathrm{kJ} /\right.$ day $\left.\mathrm{kg}^{0.75}\right), A=$ time spent active (standing + eating) (h), $T=$ total run time (h) and $C=$ cost of activity $\left(412.2 \mathrm{~kJ} /\right.$ day $\left.\mathrm{kg}^{0.75}\right)$.

The mean response data (THP, RHP, RQ, and the average $T_{\text {rectal }}$ and RR over the 20-h period) were analyzed using the general linear model procedure in SAS and using the effects of group, period, animal within group, temperature treatment (TRT), and previous treatment (carryover) effects. Least-squares means were used to determine treatment mean differences. Activity (percentage of time spent standing, lying, and eating) was analyzed with the additional blocking factor of person viewing the activity videotapes.

Dynamic data (dynamic THP, and concurrent $T_{\text {rectal }}$ and RR) were also analyzed using the general linear model procedure in SAS and testing for linear and quadratic effects of temperature on THP, RR, and $T_{\text {rectal }}$. Quadratic equations were developed using the general linear model produced in SAS. The temperature at which minimum THP, RR, and $T_{\text {rectal }}$ occurred was found by setting the first derivative of the regression equations equal to zero. The curve was further described by a pair of linear equations developed from dynamic data on either side of the quadratic minimum. One equation was developed from the dynamic data less than or equal to the quadratic minimum and the second equation was developed from the dynamic data greater than or equal to the quadratic minimum. These two linear equations were then solved simultaneously, to determine a breakpoint.

\section{Results}

Due to equipment failure, there was a 1-week interval between periods three and four, and there was no dynamic THP taken during the fourth period. Rectal temperature, RR and batch THP were taken during period four and included in the appropriate analyses. 
The temperature treatments had the following average actual temperatures ( \pm standard error): $18^{\circ} \mathrm{C}$ $-18.28 \pm 0.33^{\circ} \mathrm{C}, 24^{\circ} \mathrm{C}-24.26 \pm 0.28^{\circ} \mathrm{C}, 28^{\circ} \mathrm{C}-$ $28.18 \pm 0.24,32^{\circ} \mathrm{C}-31.30 \pm 0.32^{\circ} \mathrm{C}$. Pigs weighed an average of $44.5 \pm 1.2, \quad 57.9 \pm 1.2,72.6 \pm 1.2$ and $93.7 \pm 1.6 \mathrm{~kg}$ during periods one through four, respectively.

\subsection{Mean responses}

Heat production and respiration rate data are presented in Table 2. Batch THP (calculated from the analysis of the gases collected in a myler bag over the 20-h calorimeter run) was significantly affected by group, period, and TRT. The THP was significantly different for the $28^{\circ} \mathrm{C}$ TRT $(P<0.05)$; all other TRTs were not different $(P>0.10)$. Respiratory quotient was affected by TRT $(P<0.05)$. Average RR was affected by animal within group and TRT, while average $T_{\text {rectal }}$ had only a significant TRT effect $(P<0.05)$. Average RRs at 28 and $32^{\circ} \mathrm{C}$ were different from all other treatments $(P<0.05)$. Average $T_{\text {rectal }}$ was affected by only TRT $(P<0.05)$.
Average $T_{\text {rectal }}$ at $32^{\circ} \mathrm{C}$ was different from all other TRTs $(P<0.05)$. Lying activity was significantly affected by animal within group and TRT $(P<0.05)$. Pigs spent significantly more time lying at $32^{\circ} \mathrm{C}$ than at 18,24 or $28^{\circ} \mathrm{C}$. Animal within group significantly affected standing activity $(P<0.05)$. Time spent eating was significantly affected by period and TRT; pigs at 28 and $32^{\circ} \mathrm{C}$ spent significantly less time eating than pigs at either 18 or $24^{\circ} \mathrm{C}$.

\subsection{Dynamic correlations}

Polynomial regression equations developed using dynamic data for RR (calculated from a 1-min sample taken every $10 \mathrm{~min}$ ), $T_{\text {rectal }}$ (a point sample taken concurrently with the RR sample $1 / 10 \mathrm{~min}$ ), and THP (calculated from gas samples analyzed every $10 \mathrm{~min}$ ) showed significant quadratic temperature effects. First derivatives revealed threshold temperatures of $19.8,22.3$ and $27.6^{\circ} \mathrm{C}$ for RR, $T_{\text {rectal }}$, and THP, respectively (Table 3). A set of linear equations was used to further describe the response. According to these equations, above $19.8^{\circ} \mathrm{C}$ respira-

Table 2

Mean responses to different thermal conditions

\begin{tabular}{lllll}
\hline Variable $^{1}$ & $18^{\circ} \mathrm{C}$ & $24^{\circ} \mathrm{C}$ & $28^{\circ} \mathrm{C}$ & $32^{\circ} \mathrm{C}$ \\
\hline THP $\left(\mathrm{kJ} / \mathrm{kg}^{0.75}\right.$ day) & $666.6 \pm 18.9^{\mathrm{a}}$ & $637.3 \pm 18.6^{\mathrm{a}}$ & $571.4 \pm 19.6^{\mathrm{b}}$ & $636.5 \pm 18.7^{\mathrm{a}}$ \\
$\mathrm{RHP}\left(\mathrm{kJ} / \mathrm{kg}^{0.75}\right.$ day) & $639.6 \pm 18.2^{\mathrm{a}, \mathrm{c}}$ & $617.8 \pm 17.9^{\mathrm{a}, \mathrm{c}}$ & $555.7 \pm 18.3^{\mathrm{b}}$ & $622.6 \pm 18.0^{\mathrm{c}}$ \\
RQ $(1 / 1)$ & $1.050 \pm 0.017^{\mathrm{a}}$ & $1.016 \pm 0.017^{\mathrm{a}, \mathrm{c}}$ & $0.961 \pm 0.018^{\mathrm{b}}$ & $0.968 \pm 0.018^{\mathrm{b}, \mathrm{c}}$ \\
RR $(\mathrm{bpm})$ & $44.7 \pm 2.5^{\mathrm{a}}$ & $47.5 \pm 2.4^{\mathrm{a}}$ & $60.7 \pm 2.5^{\mathrm{b}}$ & $72.6 \pm 2.8^{\mathrm{c}}$ \\
$T_{\text {rectal }}\left({ }^{\circ} \mathrm{C}\right)$ & $39.36 \pm 0.09^{\mathrm{a}}$ & $39.38 \pm 0.09^{\mathrm{a}}$ & $39.49 \pm 0.08^{\mathrm{a}}$ & $39.96 \pm 0.12^{\mathrm{b}}$ \\
Lying $(\%)$ & $93.4 \pm 0.6^{\mathrm{a}}$ & $95.3 \pm 0.5^{\mathrm{b}}$ & $96.2 \pm 0.6^{\mathrm{b}}$ & $96.7 \pm 0.6^{\mathrm{b}}$ \\
Standing $(\%)$ & $3.5 \pm 0.5$ & $2.5 \pm 0.5$ & $2.5 \pm 0.5$ & $2.4 \pm 0.5$ \\
Eating $(\%)$ & $3.1 \pm 0.3^{\mathrm{a}}$ & $2.2 \pm 0.3^{\mathrm{b}}$ & $1.3 \pm 0.3^{\mathrm{c}}$ & $0.9 \pm 0.3^{\mathrm{c}}$ \\
\hline
\end{tabular}

${ }^{\mathrm{a}, \mathrm{b}, \mathrm{c}}$ Columns with differing superscripts are significantly different $(P \leq 0.05)$.

${ }^{1} \mathrm{THP}=$ Total heat production (based on analysis of gases collected over each run-batch measurement), RHP $=$ resting heat production (calculations based on batch THP measurements ${ }^{2}$ ), $\mathrm{RQ}=$ respiratory quotient, $\mathrm{RR}=$ respiration rate, $T_{\text {rectal }}=$ rectal temperature.

${ }^{2}$ RHP is calculated based on the batch THP for an individual calorimetry measurement and the time the individual pig spent standing and eating $(A)$. $(\mathrm{RHP}=\mathrm{THP}-412.2 \cdot A / 20 \mathrm{~h})$.

Table 3

Regression coefficients and model significance of quadratic equations, developed to describe ambient temperature effects $\left(T_{\mathrm{a}}\right)$ on rectal temperature $\left(T_{\text {rectal }}\right)$, respiration rate $(\mathrm{RR})$, and total heat production (THP)

\begin{tabular}{lllr}
\hline Variable & Equation & Minimum temperature $\left({ }^{\circ} \mathrm{C}\right)$ & $P$ Value \\
\hline RR & $176.3 \pm 8.5-13.1 \pm 0.72 T_{\mathrm{a}}+0.33 \pm 0.015 T_{\mathrm{a}}^{2}$ & 19.8 & $<0.0001$ \\
$T_{\text {rectal }}$ & $43.87 \pm 0.15-0.42 \pm 0.01 T_{\mathrm{a}}+0.009 \pm 0.0002 T_{\mathrm{a}}^{2}$ & 22.3 & $<0.326$ \\
THP & $1200.4 \pm 34.5-44.1 \pm 2.9 T_{\mathrm{a}}+0.8 \pm 0.06 T_{\mathrm{a}}^{2}$ & 27.6 & $<001$ \\
\hline
\end{tabular}


Table 4

Regression coefficients and model significance of linear equations, developed to describe ambient temperature effects $\left(T_{\mathrm{a}}\right)$ on rectal temperature $\left(T_{\text {rectal }}\right)$, respiration rate $(\mathrm{RR})$, and total heat production (THP)

\begin{tabular}{llrl}
\hline Variable & Equation & $P$ Value & $R^{2}$ \\
\hline $\mathrm{RR}$ & & & \\
$T_{\mathrm{a}} \leq 19.8^{\circ} \mathrm{C}$ & $52.1 \pm 9.7-0.2^{*} \pm 0.6 T_{\mathrm{a}}$ & 0.7813 & 0.000 \\
$T_{\mathrm{a}} \geq 19.8^{\circ} \mathrm{C}$ & $-64.0 \pm 3.6+4.9 \pm 0.1 T_{\mathrm{a}}$ & $<0.0001$ & 0.294 \\
& Intersection point $=23.1^{\circ} \mathrm{C}$ & &
\end{tabular}

$T_{\text {rectal }}$

$T_{\mathrm{a}} \leq 22.3^{\circ} \mathrm{C} \quad 39.32 \pm 0.074+0.003^{*} \pm 0.004 T_{\mathrm{a}} \quad 0.4435 \quad 0.000$

$T_{\mathrm{a}} \geq 22.3^{\circ} \mathrm{C} \quad 36.05 \pm 0.076+0.12 \pm 0.003 T_{\mathrm{a}} \quad<0.0001 \quad 0.362$

Intersection point $=26.8^{\circ} \mathrm{C}$

THP

$T_{\mathrm{a}} \leq 27.6^{\circ} \mathrm{C} \quad 857.5 \pm 12.0-10.4 \pm 0.5 T_{\mathrm{a}} \quad<0.0001 \quad 0.114$

$T_{\mathrm{a}} \geq 27.6^{\circ} \mathrm{C} \quad 416.4 \pm 41.3+6.1 \pm 1.3 T_{\mathrm{a}}{ }^{2} \quad<0.0001 \quad 0.011$

Intersection point $=26.6^{\circ} \mathrm{C}$

*Coefficient not significantly different from zero $(P>0.1)$.

tion rate increased 4.9 breaths per minute (bpm) for every increase in ambient temperature, while rectal temperature increased $0.11^{\circ} \mathrm{C}$ for every increase in temperature above $22.3^{\circ} \mathrm{C}$. Total heat production decreased $10.4 \mathrm{~kJ} / \mathrm{kg}^{0.75}$ day ${ }^{\circ} \mathrm{C}$ as temperature increased from 18 to $27.6^{\circ} \mathrm{C}$, and then increased 6.1 $\mathrm{kJ} / \mathrm{kg}^{0.75}$ day $\mathrm{C}$ as temperature increased from 27.6 to $32^{\circ} \mathrm{C}$.

These sets of linear equations were used to determine a second threshold by solving them simultaneously. The breakpoints, the point of intersection between the two linear lines, were found to be 23.1, 26.8 , and $26.6^{\circ} \mathrm{C}$ for RR, $T_{\text {rectal }}$ and THP, respectively (Table 4).

\section{Discussion}

\subsection{Mean responses}

Batch THP measurements reported in this study were 16.9 and $20.1 \%$ greater than the current American Society of Agricultural Engineers (ASAE, 1999) and American Society of Heating, Refrigerating and Air-Conditioning Engineers (ASHRAE, 1998) heat production standards under thermoneutral conditions of 18 and $24^{\circ} \mathrm{C}$, respectively. Both standards use equations developed by Bond et al. (1959) to predict heat and moisture production of growing and finishing swine. This difference in THP can be accounted for in the increase of lean growth in the new genetic lines of pigs. Protein gain of pigs of similar genetic background has been reported as $125.5 \mathrm{~g} /$ day (Brown-Brandl et al., 2000).

Total heat production measurements taken during the current study compare to other current literature values. Total heat production values reported by van Milgen et al. (1997) for the Large White barrows exposed to $26^{\circ} \mathrm{C}$ were $634.9,638.2$ and $636 \mathrm{~kJ} / \mathrm{kg}^{0.75}$ day for weights of 28,39 and $58 \mathrm{~kg}$, respectively. These values agree with the data in the current work. In a study by Brown-Brandl et al. (1998), pigs were acutely exposed to four treatments $-18,24,28$ and $32^{\circ} \mathrm{C}$, and the THP reported were 695, 661, 560624 $\mathrm{kJ} / \mathrm{kg}^{0.75}$ day. The 18 and $24^{\circ} \mathrm{C}$ TRTs were approximately $30 \mathrm{~kJ} / \mathrm{kg}^{0.75}$ day higher than the current study, but the same trend was observed in both studies.

These small differences could be a difference in feed intake or activity level due to the experimental protocols. In the current study, pigs wore vests to hold data loggers, respiration sensors around their necks, and rectal probes, none of which were required in the earlier study (Brown-Brandl et al., 1998). (Both the vest and the rectal probe add some stress to the animal which could cause a reduction in feed intake, and changes in activity level.) Feed intake impacts heat production by adding the heat produced during the breakdown and utilization of the feed (Blaxter, 1989).

Average RR increased from $44.7 \mathrm{bpm}$ at $18^{\circ} \mathrm{C}$ to $72.6 \mathrm{bpm}$ at $32^{\circ} \mathrm{C}$ (Table 2). Brown-Brandl et al. (1998) reported RR (measured manually by flank movement) and temperature to be exponentially correlated. From this prediction equation, RR would be approximately $23.3 \mathrm{bpm}$ at $18^{\circ} \mathrm{C}, 47.3 \mathrm{bpm}$ at $24^{\circ} \mathrm{C}, 75.7 \mathrm{bpm}$ at $28^{\circ} \mathrm{C}$, and $121.3 \mathrm{bpm}$ at $32^{\circ} \mathrm{C}$.

These numbers agree with the current study at the two mid-points, but seem to be lower at $18^{\circ} \mathrm{C}$ and higher at $32^{\circ} \mathrm{C}$. Liao and Veum (1994) reported RR (measured manually) to be 25.8 and $26.0 \mathrm{bpm}$ at $23^{\circ} \mathrm{C}$ compared to $57.8 \mathrm{bpm}$ at a constant $33^{\circ} \mathrm{C}$ and $60.0 \mathrm{bpm}$ at a cyclic $25-34^{\circ} \mathrm{C}$ temperatures. Lopez et al. (1991) reported RR taken in the morning to be $28.6 \mathrm{bpm}$ at $20^{\circ} \mathrm{C}$ and $41 \mathrm{bpm}$ in a cyclic $25.5-35^{\circ} \mathrm{C}$ 
treatment, and in the afternoon 37.6 at $20^{\circ} \mathrm{C}$ and 69.3 bpm in the cyclic treatment.

All three studies reported lower RR at thermoneutral conditions than was reported in the current study. There are a few possible explanations. First, the pigs in this study were required to wear a vest and a respiration sensor around their neck. This could have changed the heat loss characteristics such that the pig had to rely on some latent heat loss at the lower temperatures. However, if this was the case, the respiration would have been higher for all temperatures, especially the $32^{\circ} \mathrm{C}$, which was not the case.

On close examination of the respiration rate data at the lower temperatures, double peaks can be found (Fig. 1). Currently the raw respiration curves are analyzed and RR are generated using software developed in the laboratory. The software program counts some of these double peaks as two respirations, and some as just one respiration. The source of these double peaks is unknown; it has been hypothesized to be related to the actual respiration or possibly related to blood flow in the carotid artery. These peaks appear in records where the temperatures were within the thermoneutral range; however, they do not appear on the same place in the respiration curve.
Nonetheless, these double peaks could account for the higher baseline respiration rates reported in this experiment as compared to other literature values. This phenomenon is being investigated further. In spite of this, breakpoints revealed by the analysis of this data should be valid because this phenomenon occurs only under the thermoneutral conditions.

Average $T_{\text {rectal }}$ was not significantly different for the 18,24 and $28^{\circ} \mathrm{C}$ TRT. The average $T_{\text {rectal }}$ for the $32^{\circ} \mathrm{C}$ TRT was significantly higher than all other treatments. Ingram (1964) saw a similar response pigs exposed to temperatures ranging from -5 to $30^{\circ} \mathrm{C}$ were not positively correlated with temperature. However, pigs exposed to $35^{\circ} \mathrm{C}$ had an average $T_{\text {rectal }} 1-1.6^{\circ} \mathrm{C}$ higher than all other temperature treatments.

Pigs spent more time lying and less time eating $(P<0.05)$ as temperature increased. Standing activity did not show any trend with changing temperature, while animal differences were significant. During an activity event heat production can increase 400-420 $\mathrm{kJ} / \mathrm{kg}^{0.75}$ day (McDonald et al., 1988; Noblet et al., 1993; van Milgen et al., 1998), therefore activity differences could account for some of the variation in THP. Resting heat production was calculated using Eq. (1). Removing the effects of activity on THP comparing significant differences between RHP and

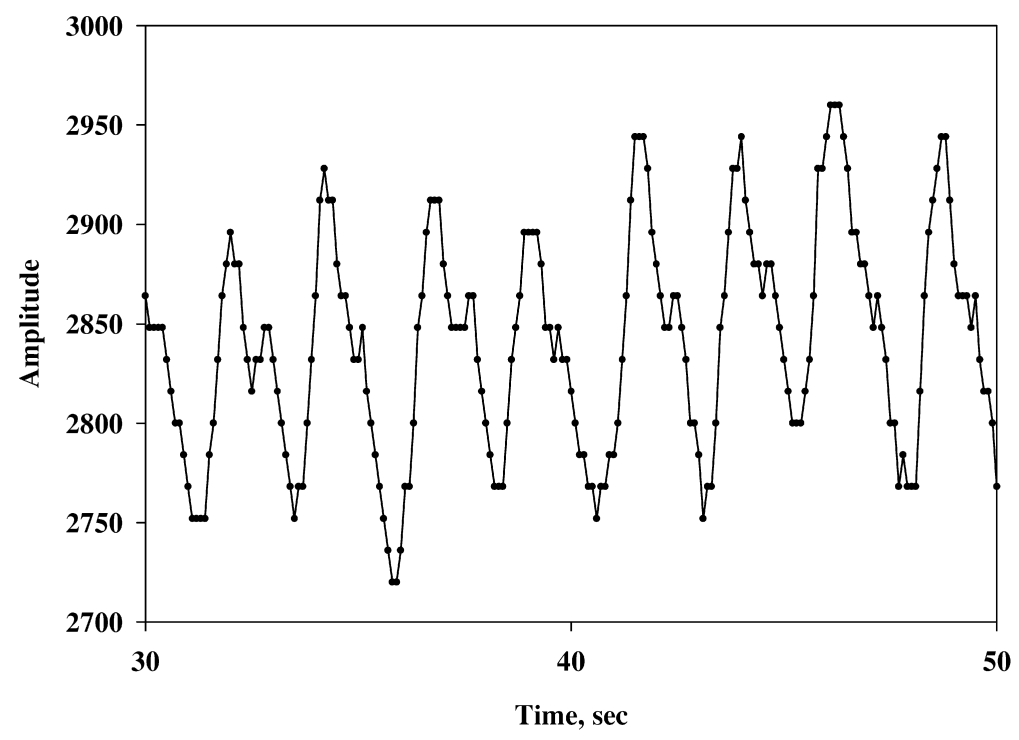

Fig. 1. Sample respiration data as recorded by an acoustic respiration rate sensor. Note the double peaks on the respirations which could account for the higher average respiration rates at the lower frequency. 
THP - revealed significant differences between the RHP at 28 and $32^{\circ} \mathrm{C}$.

\subsection{Dynamic correlations}

Respiration rate from a variety of livestock species has been described by various non-linear functions including an exponential function (Brown-Brandl et al., 1998 - pigs), quadratic function (Spain and Spiers, 1996 - dairy calves; Hahn et al., 1997 feedlot cattle), a series of linear equations (Hahn et al., 1997 - feedlot cattle), a sigmoid relationship (Kibler and Brody, 1950 - beef and dairy cows), and others. Rectal temperature (Ingram, 1964 - pigs) and THP (Brody, 1945 - general) have also been described as non-linear functions.

The quadratic equations developed for RR, $T_{\text {rectal }}$, and THP reveal minimums which can be related to physiological transition points. These transition points define the transition from thermoneutral to stressful temperatures. Thermoneutrality has been defined various ways including: the ambient temperature where minimum THP occurs, or the ambient temperature at which an animal does not employ any thermoregulatory devices or body energy reserve to maintain its body temperature (Brody, 1945). Using those two definitions any of the breakpoints could be defined as the upper critical temperature.

Neither RR nor $T_{\text {rectal }}$ had a significant linear relationship with temperatures below the quadratic minimum. It can be concluded that environmental temperature did not affect either RR or $T_{\text {rectal }}$ below their respective quadratic minimums. Using the definition of thermoneutrality, it stands to reason that an animal in the thermoneutral zone is not physiologically challenged by temperature so $T_{\text {rectal }}$ and RR probably would not be correlated to environmental temperature in this range. However, above the quadratic minimum the linear equations from RR and $T_{\text {rectal }}$ were significant.

Both methods of determining a breakpoint - either by using a quadratic minimum or by using the intersection of the two linear equations - found that RR had the lowest breakpoint temperature. This would indicate that RR is the first to be affected as environmental temperature increases. With $T_{\text {rectal }}$ being next, and last to be affected would be THP. This scenario seems to be logical. The animals' first level of defense against heat stress is to increase the heat losses; sensible heat losses by behavior (not measured in this study), and latent heat losses, mainly through the increase in RR in panting species, like pigs (Brody, 1945). When these methods are no longer sufficient, $T_{\text {rectal }}$ starts to increase. Finally THP starts to increase, which is caused from increase in muscle activity from panting and moving about, and the Van 't Hoff effect. The Van 't Hoff effect results in an increase in THP due to the increasing rate of reactions in the body with increasing core body temperature.

\section{Conclusions}

Measurements of THP, $T_{\text {rectal }}$, and RR showed typical responses to increasing temperature.

Numerically THP decreased from 18 to $28^{\circ} \mathrm{C}$ and then increased at $32^{\circ} \mathrm{C}$; although only THP reported for $28^{\circ} \mathrm{C}$ was significantly different. Total heat production measurements showed that the current design criteria for finishing swine housing are approximately $18.5 \%$ low under thermal neutral conditions. Rectal temperature and RR increased nonlinearly with increasing temperature.

Dynamic measurements revealed quadratic responses for THP, $T_{\text {rectal }}$, and RR. Quadratic minimums revealed breakpoints for all three parameters. The relationships between these three parameters and ambient temperature were investigated further by developing linear equations to describe the response above and below the quadratic minimum. Rectal temperature and RR were not linearly dependent on temperature below the quadratic minimum. From this, it can be concluded that the pigs were in the thermoneutral zone between $18^{\circ} \mathrm{C}$ (lowest treatment temperature) and these two quadratic minimums $\left(19.8^{\circ} \mathrm{C}-\mathrm{RR}\right.$ and $\left.22.3^{\circ} \mathrm{C}-T_{\text {rectal }}\right)$. Above the quadratic minimum RR increased $4.9 \mathrm{bpm}$ and $T_{\text {rectal }}$ increased $0.11^{\circ} \mathrm{C}$ for every $1^{\circ} \mathrm{C}$ increase in temperature. Total heat production was significantly affected by temperature above and below the quadratic minimum. The quadratic response of THP is a typical response for acute heat stress.

Respiration rate had both the lowest quadratic minimum and breakpoint temperature; this indicates that RR could be an early indicator of heat stress. 


\section{Note}

Names are necessary to report factually on available data; however, the USDA neither guarantees nor warrants the standard of the product, and the use of the name by USDA implies no approval of the product to the exclusion of others that may also be suitable.

\section{References}

ASAE, 1999. ASAE Standards, 44th Edition. EP270.5. Design of Ventilation Systems For Poultry and Livestock Shelters. ASAE, St. Joseph, MI.

ASHRAE, 1998. ASHRAE Fundamentals. Environmental Control For Animals and Plants - Physiological Considerations. ASHRAE, New York.

Blaxter, K., 1989. Energy Metabolism in Animals and Man. Cambridge University Press, Cambridge.

Bond, T.E., Kelly, C.F., Heitman, Jr. H., 1959. Hog house air conditioning and ventilation data. Trans. ASAE 2 (1), 1-4.

Brody, S., 1945. Bioenergetics and Growth. Reinhold, New York.

Brown-Brandl, T.M., Nienaber, J.A., Turner, L.W., 1998. Acute heat stress effect on heat production and respiration rate in swine. Trans. ASAE 41 (3), 789-793.

Brown-Brandl, T.M., Nienaber, J.A., Turner, L.W., Yen, J.T., 2000. Manual and thermal induced feed intake restriction on finishing barrows. Part II: Effects on heat production, activity, and organ weights. Trans. ASAE 43 (4), 993-997.

Eigenberg, R.A., Brown-Brandl, T.M., Nienaber, J.A., 2000. Development of a respiration rate monitor for swine. ASAE Meeting Presentation 004016. American Society of Agricultural Engineers, St. Joseph, MI.

Hahn, G.L., Nienaber, J.A., Eigenberg, R.A., 1993. Environmental influences on the dynamics of thermoregulation and feeding behavior in cattle and swine. In: Proc. Int. Livest. Environ. Symp. IV, Coventry, 6-9, pp. 1106-1116.

Hahn, G.L., Parkhurst, A.M., Gaughan, J.B., 1997. Cattle respiration rate as a function of ambient temperature. Mid-Central ASAE Meeting Presentation MC-97121. American Society of Agricultural Engineers, St. Joseph, MI.
Harmon, J.D., Xin, H., Shao, J., 1997. Evaluation of the thermal needs of the early weaned pig. Trans. ASAE 40 (6), 1693 1698.

Ingram, D.L., 1964. The effect of environmental temperature on body temperature, respiratory frequency and pulse rate in the young pig. Res. Vet. Sci. 4, 348-356.

Kibler, H.H., Brody, S. 1950 . Effects of temperature, 50 to $105^{\circ} \mathrm{F}$ and 50 to $9^{\circ} \mathrm{F}$ on heat production and cardiorespiratory activity in Brahman, Jersey and Holstein cows. Res. Bull. 464 (Environ. Physio. and Shelter Engineering Series XI), MO Agric. Exp. Sta. Univ.

Kuehl, R.O., 1994. Statistical Principles of Research Design and Analysis. Duxbury Press, Belmont, CA.

Liao, C.W., Veum, T.L., 1994. Effects of dietary energy intake by gilts and heat stress from days 3 to 24 or 30 after mating on embryo survival and nitrogen and energy balance. J. Anim. Sci. 72, 2369-2377.

Lopez, J., Jesse, G.W., Becker, B.A., Ellersieck, M.R., 1991. Effects of temperature on the performance of finishing swine: I. Effects of a hot, diurnal temperature on average daily gain, feed intake, feed efficiency. J. Anim. Sci. 69, 1843-1849.

McDonald, T.P., Jones, D.D., Barrett, J.R., Albright, J.L., Miles, G.E., Nienaber, J.A., Hahn, G.L., 1988. Measuring the heat increment of activity in growing-finishing swine. Trans. ASAE 31 (4), 1180-1186.

Nienaber, J.A., Hahn, G.L., Eigenberg, R.A., Korthals, R.L., Yen, J.T., Harris, D.L., 1997. Genetic and heat stress interaction effects on finishing swine. In: Proc. Int. Livest. Environ. Symp. IV, Coventry, 6-9, pp. 1017-1023.

Nienaber, J.A., Maddy, A.L., 1985. Temperature-controlled multiple chamber indirect calorimeter-design and operation. Trans. ASAE 30 (6), 1772-1775.

Noblet, J., Shi, X.S., Dubois, S., 1993. Energy cost of standing activity in sows. Livest. Prod. Sci. 34, 127-136.

Spain, J.N., Spiers, D.E., 1996. Effects of supplemental shade on thermoregulatory response of calves to heat challenge in a hutch environment. J. Dairy Sci. 79, 639-646.

van Milgen, J., Noblet, J., Dubios, S., Bernier, J.F., 1997. Dynamic aspects of oxygen consumption and carbon dioxide production in swine. Br. J. Nutr. 78, 397-410.

van Milgen, J., Bernier, J.F., Lecozler, Y., Dubios, S., Noblet, J., 1998. Major determinants of fasting heat production and energetic cost of activity in growing pigs of different body weight and breed/castration combination. Br. J. Nutr. 79, 1-9. 